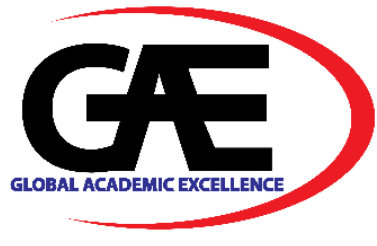

\title{
DIRECTORS' DUTY AND LIABILITY IN INSOLVENT TRADING
}

\author{
Shereen $\mathrm{Khan}^{1 *}$, Nasreen Khan ${ }^{2}$, Olivia Tan Swee Leng ${ }^{3}$ \\ 1 Faculty of Management, Multimedia University, Malaysia \\ Email: shereen.khan@mmu.edu.my \\ 2 Faculty of Management, Multimedia University, Malaysia \\ Email: nasreen.khan@mmu.edu.my \\ 3 Faculty of Management, Multimedia University, Malaysia \\ Email: oliviatan@mmu.edu.my \\ * Corresponding Author
}

\section{Article Info:}

\section{Article history:}

Received date: 25.10 .2020

Revised date: 17.10 .2020

Accepted date: 22.11 .2020

Published date: 06.12.2020

\section{To cite this document:}

Khan, S., Khan, N, \& Tan, O. S.L. (2020). Directors' Duty and Liability in Insolvent Trading. International Journal of Law, Government and Communication, 5 (21), 130-137.

DOI: $10.35631 /$ IJLGC.5210010.

This work is licensed under $\underline{\text { CC BY 4.0 }}$ (c)

\begin{abstract}
:
The effect of the novel coronavirus (Covid-19) pandemic has resulted in current and future liquidity, balance sheet, and cash flow problems. There is an anticipated decline in the profitability of the businesses during this uncertain period and attention has been turned to the directors' 'duties and liabilities' to creditors when the company is on the verge of insolvency. Directors have to strike a balance among the shareholders, creditors, and workers in the corporate restructuring process. In engaging with these stakeholders during the transformation process, the directors play a key role. It is about quick choices and decisions to be taken to save a business on the verge of insolvency, and it is therefore vital that directors act at the first sign of financial distress. There is a general duty for directors not to trade when insolvent or close to the point of insolvency. Directors also have a contractual obligation to avoid insolvent trading. This article discusses the duties of directors under the Companies Act 2016 (CA 2016) to avoid insolvent trading. It further discusses by analysing based on the comparative study with other selected jurisdictions. This article proposes that while it is important to protect creditors' interest by making the directors personally liable for insolvent trading, for the best interest of all stakeholders, there should be a balance between the security of creditors and the rescue of the company.
\end{abstract}

Keywords:

Directors’ Duties; Insolvent Trading; Restructuring 


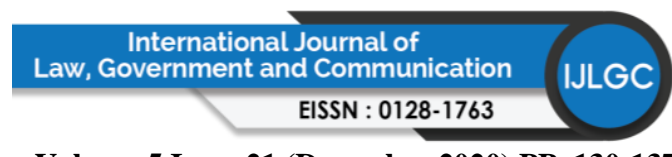

Volume 5 Issue 21 (December 2020) PP. 130-137

DOI 10.35631/IJLGC.5210010

\section{Introduction}

The effect of the novel coronavirus (Covid-19) pandemic has resulted in current and future liquidity, balance sheet and cash flow problems. There is an anticipated decline in the profitability of the businesses during this uncertain period and attention has been turned to the directors' 'duties and liabilities' to creditors when the company is on the verge of insolvency. Directors have to strike a balance among the shareholders, creditors and workers in corporate restructuring process. In engaging with these stake holders during the transformation process, the directors play a key role. It is about quick choices and decisions to be taken to save a business on the verge of insolvency, and it is therefore vital that directors act at the first sign of financial distress. There is a general duty for directors not to trade when insolvent or close to the point of insolvency. Directors also have a contractual obligation to avoid insolvent trading. This article discusses on the duties of directors under the Companies Act 2016 (CA 2016) to avoid from insolvent trading.

\section{Overview of Breach of Directors' Duties in Insolvent Trading}

The general duties of directors owed to the company and subsequently to creditors are rather broad. The responsibility of directors to creditors beyond those owed to the corporations tends to be in conflict with the fundamental principles of corporate law focused on the definitions of distinct corporate identity and limited liability. These laws are meant to favour shareholders and eventually provide the economy with advantage. It is a settled rule that, at the time of imminent insolvency, directors have an obligation to take into account of the needs of creditors. While there is a general duty of directors not to trade when insolvent or close to the point of insolvency, the implementation statutory requirement to be proactive on the part of director will result in extending the corporate rescue procedures to be introduced as a part of the duties of the directors.

The House of Lords in Salomon v A. Salomon \& Co. Ltd ${ }^{l}$ defined the basic company function of separate legal personality. The case was later referred to as the "Salomon concept" that recognises members' limited liability. The Court may order the lifting of the corporate veil in certain circumstances, especially in cases of fraudulent unfair trade and under certain statutory provisions. When one carries on business with the intention of defrauding creditors or for dishonest purposes, fraudulent trading occurs. Wrongful trading applies to a case in which a company has entered an effective insolvency stage and proceeds to operate despite the fact that the company's directors are aware of or should have known prior to the company's dissolution that there was no reasonable prospect of the company preventing the dissolution due to its insolvency. Different jurisdictions have codified these fraudulent and wrongful transactions into their respective legislation and directors are held to be liable accordingly.

In the United Kingdom, the United States and Malaysia, insolvent trading is referred to as 'wrongful trading' and 'fraudulent trading' whereas in Australia as 'insolvent trading'. The legislation prohibits the directors from continuing to trade and imposes an obligation on directors to prevent from insolvent trading. The duties of directors are generally towards the company. The interest of creditors are protected by directors' indirect fiduciary obligations to creditors in situations where corporations are nearly insolvent. The interests at stake in such

\footnotetext{
${ }^{1}$ [1897] AC 22

Copyright $\odot$ GLOBAL ACADEMIC EXCELLENCE (M) SDN BHD - All rights reserved
} 


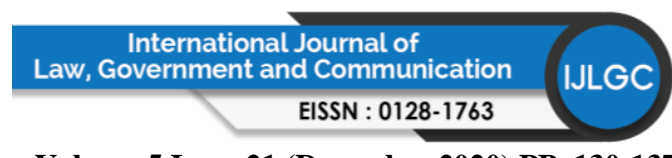

Volume 5 Issue 21 (December 2020) PP. 130-137

DOI 10.35631/IJLGC.5210010

situations are those of creditors whose interest is at stake by the trading of the company. There are the legislations to protect the creditors by prohibiting the company from insolvent trading.

\section{Breach of Director's Duty in Malaysia}

There are few effective provisions which impose duties on creditors directly or indirectly on company directors in Malaysia. In recent years, several jurisdictions have added a growing number of legislative protections designed to protect creditors and enforce liability on directors. The Companies Act 2016 improved the common law position by incorporating the insolvent trade rules to protect the creditors.

The Companies Act 2016 (CA 2016), which includes different rules regulating the term for civil lawsuits and criminal acts, describes fraudulent trading. Wrongful trading is described in s.539 (3) of the CA 2016 where the action can only be brought against the company officials (most commonly the company directors), fraudulent trading actions can be brought against any person who was knowingly a party to the conduct of the business. Thus, the directors can incur personal liability under the CA 2016 for allowing the company to trade while insolvent. In this regard, section 539(3) of the CA 2016 provides that:

'If in the course of winding up of a company or in any proceedings against a company, an officer of the company who knowingly was a party to the contracting of a debt had, at the time the debt was contracted, no reasonable or probable ground of expectation, after taking into consideration the other liabilities, if any, of the company at the time, of the company being able to pay the debt, commits an offence and shall, on conviction, be liable to imprisonment for a term not exceeding five years or to a fine not exceeding five hundred thousand ringgit or to both."

In s. 540 (1) of CA 2016, 'fraudulent trading' is defined as follow:

"If in the course of the winding up of a company or in any proceedings against a company it appears that any business of the company has been carried on with intent to defraud the creditors of the company or creditors of any other person or for any fraudulent purpose, the Court on the application of the liquidator or any creditor or contributory of the company, may, if the Court thinks proper so to do, declare that any person who was knowingly a party to the carrying on of the business in that manner shall be personally responsible, without any limitation of liability, for all or any of the debts or other liabilities of the company as the Court directs."

In Kawin Industrial Sdn. Bhd. (in liquidation) v. Tay Tiong Soong ${ }^{2}$, the question before the court relates to the interpretation of s. 304(1) of CA 1965 which is pari materia with s. 540(1) of CA $2016 .{ }^{3}$ The issue was whether the facts of the case are within the scope of that provision. The Court held that the language of this provision is very clear. In order to constitute fraud, it is not necessary for the creditors to have actually been defrauded as long as there is an intention to defraud. An attempt to defraud in this regard is an attempt to deprive creditors or other creditors of economic benefit or to impose such economic losses on them.

\footnotetext{
2 [2009]1MLJ 723 at pg.724

${ }^{3}$ Coleman v The Queen (1987) 5 ACLC 766

Copyright $\odot$ GLOBAL ACADEMIC EXCELLENCE (M) SDN BHD - All rights reserved
} 


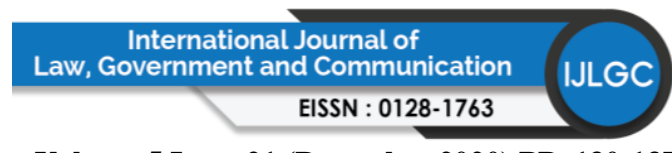

Volume 5 Issue 21 (December 2020) PP. 130-137

DOI 10.35631/IJLGC.5210010

The phrase 'with intent to defraud creditors ... or for any fraudulent purpose' within the context of s. 540 (1) of CA 2016 had been interpreted in a number of cases to include (i) "a situation where a company continues to carry on business and to incur debts at a time when there is to the knowledge of the directors no reasonable prospect of the creditors ever receiving payment of those debts"4; (ii) that "fraud in the context of fraudulent trading connotes 'actual dishonesty involving, according to current notions of fair trading among commercial men, real moral blame"'5; (iii) "where a person who takes part in the management of a company's affairs obtains credit or further credit for the company when he knows that there is no reason for thinking that funds will become available to pay the debts when it becomes due or shortly thereafter"6; (iv) "where a company accepted the purchase price in advance knowing that it could not supply the goods and would not repay the advance paid"7 and (v) "a person was knowingly party to the business of a company having been carried out with intent to defraud creditors if at the time when debts were incurred by the company he had no good reason for thinking that funds would be available to pay those debts when they became due or shortly thereafter and there was dishonesty involving real moral blame according to current notions of fair trading".

In the case of JCT Ltd. v. Muniandy Nadasan \& Ors. ${ }^{8}$, it was concluded that "a single act to defraud the creditors of the company in the course of business was sufficient to trigger fraudulent trading. Through its managing director, the appellant company dealt in transactions that fraudulently gave creditors the impression that the company was a continuing concern when it was actually insolvent".

The phrase 'if it appears' in s. 540 (1) needs only a lower degree of proof. The directors owe a responsibility to the company and the creditors to ensure that the company's affairs are properly handled and that its assets are not dissipated or abused to the disadvantage of the creditors or to the detriment of the creditors ${ }^{9}$. The main objective of $\mathrm{s.540}$ is to place a statutory duty on the directors of the insolvent company to pay their creditors if they have engaged in fraudulent trading. Civil litigation for unlawful trading is not limited to the businesses which are in the process of winding-up proceedings, such an action may also be available in the process of any other legal proceedings against the company. ${ }^{10}$ When s. 540 (1) and (5) state that with fraudulent intent, a person who was "knowingly a party to carrying on business", spells out an aspect of deceit to be displayed in order to trigger dishonest trading. It is not enough simply to do business with the knowledge that the company would not be able to pay later to cause "fraudulent trading". The Court in Siow Yoon Keong v. H Rosen Enginnering BV ${ }^{11}$, held that it must be shown that there is an element of dishonesty on the part of the alleged defendant when the business at issue was conducted.

\footnotetext{
${ }^{4}$ Re William C Leitch Bros Ltd [1932]2 Ch 71

${ }^{5}$ Re Patrick \& Lyon Ltd [1933]Ch 786 at pg.790

${ }^{6} R v$ Grantham [1984]3 All ER 166, CA

${ }^{7}$ Re Gerald Cooper Chemicals Ltd [1978]2 All ER 49

8 [2016] 6 MLJ 635

${ }^{9}$ Winkworth v Edward Baron Development Co Ltd \& Ors. [1987]1 All ER 114, HL

${ }^{10}$ Haidar J in Tang Eng Iron Works Co Ltd v Ting Ling Kiew \& Anor, Originating Summons No Kg 144 Of 1989 High Court (Kuching) 1990-2 MLJ 440.

11 [2003] 4 MLJ 569.

Copyright $\odot$ GLOBAL ACADEMIC EXCELLENCE (M) SDN BHD - All rights reserved
} 


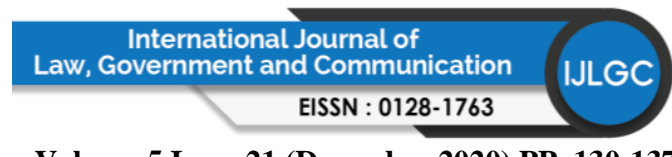

Volume 5 Issue 21 (December 2020) PP. 130-137

DOI 10.35631/IJLGC.5210010

If a person is merely accused of incurring a debt without reasonable prospect of repayment, s.540 (2) allows the liquidator, creditor or contributor as follow:

"Where a person has been convicted of an offence under subsection 539(3) in relation to the contracting of such a debt as is referred to in that section, the Court on the application of the liquidator or any creditor or contributory of the company may, if the Court thinks proper so to do, declare that the person shall be personally responsible without any limitation of liability for the payment of the whole or any part of that debt."12

Thus, an action must be first brought before s.540 (1) CA 2016 by the prosecutor, and must be completed and effective against the delinquent directors. This is likely to create unnecessary challenges for creditors or liquidators if they wish to obtain remedy for damages resulting from a continuation of trade in a civil case. Where, at the request of the liquidator or any creditor or contributor of the corporation, a person has been convicted of an offence under s. 539 (3) in accordance with the contradiction of the debt referred to in that section, the Court may, if it finds it necessary to do so, declare that the person is personally liable without restriction of liability for the payment of the whole or any part of the debt.

Generally, no particular distinction is made as to what constitutes 'intent to defraud' in civil and criminal cases. The standard of review in civil claim may be slightly lighter than that under the criminal action. ${ }^{13}$ The purpose to defraud, however, can be identified when the party in question closes its eyes to the obvious out of a deliberate fear that to enquire further will confirm an already existing presumption of wrongdoing. In the criminal context however, an objective approach may be adopted which might help the prosecutor in establishing his case which supposedly require a burden beyond reasonable doubt. If a director has violated the 'statutory duty of care' is determined by taking into account of the actual amount of care and diligence exercised and comparing it with the level of care and diligence that would have been exercised by a reasonable person with the same responsibilities. If the director has any additional knowledge, skill and experience, the court would also consider whether he had exercised the degree of care and diligence that he should have exercised in view of the additional knowledge, skill and experience that he has. ${ }^{14}$

Based on the data received from the Company Commission of Malaysia (CCM), most of the cases prosecutes by CCM with regards to breached of directors' duties are mainly relating to some other duties such as failure to hold an Annual General Meeting (AGM), failure to lodge the annual return to the Registrar of Companies, failure to table the company's profit and loss account in AGM, making false statements, offering illegal investment and submitting misleading information to CCM. Only $10 \%$ of the cases prosecuted by CCM are on breach of directors' duties as to fiduciary duty and there is no reported case for breach of directors' duty as to 'fraudulent trading'. Thus, existing provisions are not relatively ineffective to deter the

\footnotetext{
12 Section 540 (2) CA 2016.

13 in $R v$ Clowes (No 2) [1994] 2 All ER 316 at pp 332-334, where in a proper case a defendant holding a subjective belief that he was acting lawfully would not be thought dishonest, as he believes he is acting honestly by ordinary standards.

${ }^{14}$ Section 213 (2) CA 2016

Copyright $\odot$ GLOBAL ACADEMIC EXCELLENCE (M) SDN BHD - All rights reserved
} 


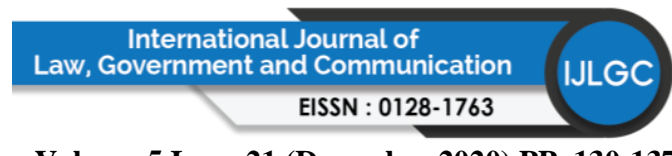

Volume 5 Issue 21 (December 2020) PP. 130-137

DOI 10.35631/IJLGC.5210010

directors from breach of their duties as to insolvent trading since it is a requirement to prove the element of fraud to take the action under the section 540 (CA 2016) and Malaysia needs separate provisions relating to breach of directors' duty in the case of insolvent trading.

\section{Comparative Analysis of Directors' Duties in Other Jurisdictions}

In the United Kingdom, a director may be held to be liable under section 214 of the Insolvency Act 1986 if the director allows the trading of the company to continue and he will be incur further liability if he has the knowledge or should have the knowledge that the company may result in insolvency unless it can be proved that every step was taken by the director to lessen the loss of the creditors concerned.

Likewise, Singapore Companies Act has ss.339 (3) and 340 (1) dealing with the contracting debts where there is no possible way of payment of the debts which have similar provisions in CA 2016 of Malaysia. The disqualification of incompetent directors of insolvent company is addressed in section 149(2) (b) of the Singapore Act.

The Australia Companies Act 2001, section 588 G, deals with the inability of the directors to prevent insolvent trading and subject to four specific defences. Contravention of this section may give rise to civil proceeding and criminal proceeding in some circumstances. Section 588V - X extends the responsibility to the parent company for failure to prevent a subsidiary from insolvent trading. Section 214 of the Insolvency Act 1986 of the United Kingdom sets out the same obligation on directors not to engage in wrongful trading. In fact, the most significant part of duty of care is the insolvent trading. This is subject to both civil and criminal sanctions in Australia and personal liability in most of the jurisdictions discussed above. Interpretation of the provisions relating to insolvent trading and specific available defences are still in doubt. The United States does not have any specific provision relating to insolvent trading.

There were just a few cases of duty of care and insolvent trading, but there have been more cases of insolvent trading in other jurisdictions, such as Australia and New Zealand, and the consequences for directors are serious. ${ }^{15}$ When the company trades while insolvent, directors may become directly responsible for the corporation's debts. And if one director is liable for insolvent trading, unless one of them is able to rely on the defences offered under the statue, it is probable that all will be held to be liable. In most cases, as members of a board of directors, all the directors would have the same knowledge. However, there are the legislation which allows to have an insurance against such risk if there is a possibility that a director may be held to be liable for insolvent trading. Introducing the insurance to the directors in a way would reduce their burden in case they are being sued and held to be liable personally for the breach of duties of directors in insolvent trading.

Despite the fact that Australian law has codified the insolvent trading and the provision has been established in Australian law, there are questions as to the necessity of having it in their system. It was argued that these provisions protect the creditors' interest overly and as a result

\footnotetext{
${ }^{15}$ Farrar, Directors' Duties of Care, at pg. 756.

Copyright $\odot$ GLOBAL ACADEMIC EXCELLENCE (M) SDN BHD - All rights reserved
} 


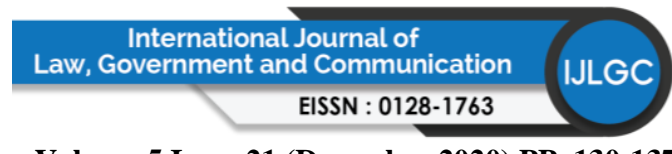

Volume 5 Issue 21 (December 2020) PP. 130-137

DOI 10.35631/IJLGC.5210010

creditors have been overly compensated. ${ }^{16}$ However, provisions relating to 'insolvent trading' are vital to protect the interest of creditors to ensure that the economy of the country is intact. Hence it is pertinent that a provision similar to that of insolvent trading in Australian Law should be codified in Malaysia.

It can be seen that Australia's approach is too strict whereas the approach in the United Kingdom is not clear. The approach in the United States seems to work well so far in their system of pro-debtor approach. To ensure that directors take the responsibility at the time of restructuring process and at the same time, not to impose too much regulation and resulting in entering into formal restructuring process too soon, there must be a balance among all these factors. A framework which strikes the best balance of all these factors and at the same time allowing the directors to have some breathing space by providing useful defences for cases where the directors has acted 'honestly and in good faith' and 'to the best interest of the company' i.e. similar to Business Judgement Rule under the Companies Act 2016. By introducing this framework, errant directors can be curbed effectively without compromising the interest of creditors involved. Like some commentators have suggested it would be interesting to refer back to the Cork Report on the basic principle of wrongful and fraudulent trading.

\section{Conclusion}

In this current situation where Malaysia is under the conditional movement control order because of the global pandemic, directors of the companies have to be extra vigilant of their duties and potential liability and not to enter into any trading if the company is near to insolvency. There are a number of businesses suffer losses and could not continue to operate and thus have to resort to closing it completely. Thus, it is vital that the directors would act prudently and take all the necessary measure to avoid themselves from being personally liable. The Companies Act 2016 impose both civil and criminal liability on the officers of the company for engaging in insolvent and fraudulent trading. It is therefore suggested that management of the company will take some precautionary measures such as having a specific business plan in the era of global pandemic, review all the transactions before entering and seek professional advice if needed be and conduct all their activities with skill, care and diligence as stated under the section 132 (1) of the Companies Act 2016 of Malaysia.

\section{References}

Andrew Keay et. al., (2020). 'Business Judgement and Director Accountability: A Study of Case-Law over Time': Journal of Corporate Law Studies Vol. 20, Issue 2.

Andrew Keay. (2020). Directors' Duties, fourth edition, Jordon Publishing.

Bruce, M., (2018). Rights and Duties of Directors. Bloomsbury Professional, London.

Chief Justice Wayne Martin, 'Official Opening Address' (Speech delivered at the Insolvency Practitioners' of Australia $16^{\text {th }}$ National Conference, Perth, 28 May 2009) 13.

Chin, J. L. (2011). Women and Leadership: Transforming Visions and Current Contexts. Forum on Public Policy: A Journal of the Oxford Round Table, (2), 1-12.

\footnotetext{
16 David Morrison, 'The Economic Necessity for the Australian Insolvent Trading Prohibition' (2003) 12 International Insolvency Review 171, 177 
Cory D Kandestin. (2007). 'The Duty to Creditors in Near-Insolvent Firms: Eliminating the "Near-Insolvency" Distinction': Vanderbilt Law Review (60) 1235, 1262

David Morrison. (2003). 'The Economic Necessity for the Australian Insolvent Trading Prohibition': International Insolvency Review 12

Gerard McCormack. (2008). 'Corporate Rescue in Singapore and the Appropriateness of Chapter 11 of the US Bankruptcy Code as a Model': Singapore Academy of Law Journal (20) 396, 425.

Ian Fletcher. (2017). The Law of Insolvency ( $5^{\text {th }}$ edt.), Sweet and Maxwell, London.

Lo, S. H. (2020). Proposals for Insolvent Trading Laws in Hong Kong: A Comparative Analysis. J. Int'l \& Comp. L., 7, 229.

Mark Byrne. (1994). 'An Economic Analysis of Directors' Duties in Favour of Creditors': Australian Journal of Corporate Law (4) 275, 277.

Michael Whincop, (1996). 'Taking the Corporate Contract More Seriously: The Economic Cases Against, and a Transaction Cost Rationale For, the Insolvent Trading Provisions': Griffith Law Review (5) 1, 1.

Niall Coburn. (2003). Coburn's Insolvent Trading: Global Investment and Fraud and Corporate Investigations $\left(2{ }^{\text {nd }} \mathrm{ed},\right) \mathrm{xi}$-xii.

Philip Wood. (2007). Principles of International Insolvency $\left(2^{\text {nd }}\right.$ edt.), Sweet \& Maxwell, London.

Ramsay, I. (2017). Personal insolvency in the 21st century: A comparative analysis of the US and Europe. Bloomsbury Publishing.

Rosemary Langford. (2015). 'The Duty of Directors to Act Bona Fide in the Interests of the Company: A Positive Fiduciary Duty? Australia and the UK Compared': Journal of Corporate Law Studies Vol. 11- Issue 1.

Rosemary Langford. (1998). 'The New Statutory Business Judgment Rule: Should it Apply to the Duty to Prevent Insolvent Trading': Companies and Securities Law Journal (16) 533.

The White Paper on Modernising Company Law by House of Commons, Trade and Industry Committee, Sixth Report of Session 2002-03 published on 13 May 2003.

Williams, R. (2015). What can we expect to gain from reforming the insolvent trading remedy?. The Modern Law Review, 78(1), 55-84. 